\title{
THE WITHIN-HOUSEHOLD SCHOOLING DECISION: A STUDY OF CHILDREN IN RURAL ANDHRA PRADESH
}

\author{
Masako OTA \\ School of Development Studies \\ University of East Anglia \\ Norwich NR4 7TJ \\ and \\ Peter G. MOFFATT \\ School of Economic and Social Studies \\ University of East Anglia \\ Norwich NR4 7TJ
}

17 January 2002

Key words: Child labour, Schooling, Birth order, Sibling composition, Intrahousehold decision-making, India

JEL Classifications: C25, J13. 


\title{
THE WITHIN-HOUSEHOLD SCHOOLING DECISION: A STUDY OF CHILDREN IN RURAL ANDHRA PRADESH
}

\begin{abstract}
Summary
Using microdata from a field survey of children in rural Andhra Pradesh, India, we estimate econometric models which aim to identify the key explanatory factors in the school versus out-of-school dichotomy. The approach differs from that of many other previous studies of child schooling, by focusing on the effects of sibling competition within the household. The value of this approach is confirmed by our findings that the schooling decision depends as much on the child's characteristics and position within the household, as on the circumstances of the household taken as a unit.
\end{abstract}

\section{Introduction}

The issue of child labour versus schooling ${ }^{1}$ has received growing attention in recent years. However, the mention of child labour tends to invoke an image of children toiling in factories to produce export goods under poor working conditions, and poverty is often considered to be its major cause. Until now, this stereotypical view has tended to govern investigations of the issue. Early historical studies focused on the experience of developed countries, where the incidence of child factory workers surged in the wake of industrialisation and then decreased virtually to zero ${ }^{2}$ (Nardinelli, 1990; Weiner, 1991). In similar vein, a large number of case studies have been devoted to children in manufacturing industries with 'hazardous' and 'exploitative' occupations such as carpet-weaving and football-stitching (Burra, 1995; Anker et al.,1998; Mishra, 2000). The truth of the matter is that child factory workers are a small minority, and $84 \%$ of the estimated total of 11.3 million child workers in India are engaged in agriculture and related sectors ${ }^{3}$.

A second respect in which the stereotypical view of child labour has guided research is the claim that poverty is the major cause. This claim is based largely on the empirical facts that the incidence of child labour tends to be higher in low-income countries, and higher among low-income households within a country. The main misapprehensions arising from these facts are the inferences that all poor children work, and that all working children are from poor households. These inferences are

\footnotetext{
${ }^{1}$ According to the 1991 Census of India (Government of India, 1991), 41\% of children aged between five and fourteen in Andhra Pradesh are 'in-between', i.e. neither work (as wage workers) nor attend school. In our data set, only $4 \%$ of out-of-school children fall into this category and the rest are engaged in either paid work, family work (e.g. cultivation) or domestic work. We define child workers as all out-of-school children, and use the terminology 'schooling versus work'.

${ }^{2}$ It should be noted that child labour still exists in some industrialised countries. For example, McKechnie and Hobbs (1998) report on children of Mexican migrants working on US farms.

${ }^{3}$ The 1991 Census of India (Government of India, 1991). The agricultural sectors referred to here include the categories of the Census: 'cultivators', 'agricultural labourers' and 'livestock, forestry, fishing, hunting and plantations, orchards and allied activities'.
} 
false, as is clearly evident in our and in other studies. ${ }^{4}$. Some of the poorest households are observed sending at least some of their children to school, while some better-off households are observed sending children to work.

Such misperceptions prevail partly because earlier studies have used the household or region as the unit of analysis (Rosenzweig, 1982; Hossain, 1990), masking the withinhousehold differences highlighted in the last paragraph. This approach has often been necessary because household survey data sets are being analysed whose original purposes are unrelated to child schooling, and which contain little or no information on individual children within the household. Our data collection was, in contrast, administered with the objective of collecting all relevant information on each individual child. The importance of shifting the focus from household to child is evident in the data: $58 \%$ of the sampled households contain a mixture of children who work and children who go to school.

The obvious way to proceed is to follow the approach of Bhalotra and Heady (1998) and Grootaert (1998), by treating each child in the sample as an individual decision making unit, in order to allow for and explain within-household differences in schooling choices. The process leading to a schooling decision for an individual child is clearly complicated, with demographic, social and cultural, as well as economic factors entering the decision-making process. Taking into consideration all of these types of factor simultaneously, it is desirable to explain firstly why some children go to school while others do not, and secondly what process operates within the household for deciding which of the children will go to school. We therefore use binary data analysis to investigate exactly how demographic factors such as age, gender and birth order enter the schooling decision, while controlling for household characteristics and community circumstances.

Section 2 contains a literature review of models of the schooling-work decision. Section 3 presents a model of the schooling decision. Section 4 describes the data and the econometric modelling strategy, and then reports and interprets the results. Section 5 concludes.

\section{Existing models of the schooling-work decision}

From the previous literature on the determinants of child labour and schooling, three broad approaches may be identified. Each has advantages and disadvantages. This section examines each in turn, thus providing motivation for the approach taken in this paper.

\subsection{Fertility decision models}

An early fertility decision model, and a point of departure in analysing the determinants of child labour, is the 'quantity-quality' model of Becker and Lewis (1973). This model is built on the assumption that high fertility in developing

\footnotetext{
${ }^{4}$ Lieten (2000) quotes an interview with a father in a northern Indian village, saying "we are poor, but not so poor that we cannot send our children to school." See also Bhatty (1998) and the PROBE Team (1999) for field-based evidence, as well as Ray (1999; 2000a; 2000b) and Psacharopoulos (1997) for quantitative evidence, that poverty is not the major determinant of child labour.
} 
countries results from the high perceived economic value of children, and is used to investigate what triggers a transition in parents' preference - from quantity to quality of children. The models in this class examine a household's joint decision on: how many children it has; how children's time is allocated to wage work, family work and schooling; and how resources are distributed among household members.

A substantial amount of empirical work has followed this theoretical contribution (for example, Rosenzweig and Evenson, 1977; Levy, 1985; Kanbargi, 1991). The wide diversity of research aims, data sets and variable definitions make it hard to draw general conclusions from this body of literature. However, some common results emerging are that: a rise in parents' educational levels has a strong negative effect on fertility and a strong positive effect on schooling; child labour-force participation is positively related to the child's wage; household income (usually proxied by adult wage), although not being the decisive factor, appears to have a positive effect on schooling. Other variables representing wealth, such as land-holding, have ambiguous effects, showing positive effects in some studies and negative in others.

Fertility decision models have the virtues of simplicity and convenience, and can identify which types of household are more likely to choose to educate their children. They are also particularly relevant to the case of the schooling-work choice in rural areas, which is of interest here. However, their assumptions of unitary utility of the household and unitary decisions have been challenged theoretically and empirically. Their problem is that, since they treat the children of a household in aggregate, summarising their educational status with, for example, 'enrolment indices' (Rosenzweig and Wolpin, 1982), they have no power to predict the extent to which all children in a household will be equally educated.

\subsection{Labour supply models}

The standard model of labour supply in neoclassical economics amounts to a utility maximising choice of consumption-leisure combination. Dynamic extensions to this model, namely human capital investment models (see for example Alderman and Gertler, 1997, and Jafarey and Lahiri, 1999), consider the choice between work and education, and incorporate the trade-off between current income and the higher future income that is the return from education. In such models, time is often divided into two periods: in the first, parents either invest in childrens' schooling or send them to work; in the second, parents rely on their children's earnings for their own welfare. Parents make choices in order to maximise their lifetime utility which depends on consumption in the first and second periods, subject to intertemporal budget constraints. These choices are usually modelled in the framework of a dynamic optimisation problem.

Such dynamic models are useful in explaining differences in schooling by gender (see Pscharopoulos and Woodhall, 1985; Strauss and Tomes, 1995; Alderman and Gertler, 1997).

Although there is some evidence in the literature that rates of return to female education is higher than to males', we have reasons for expecting the opposite to be 
true $^{5}$. Firstly, female earnings are generally lower than male earnings. Secondly, daughters in patrilineal societies do not contribute economically to their natal families after marriage to the same extent as sons do. Thirdly, a higher educational level attained by a girl tends to lead to a higher amount of dowry incurred by parents ${ }^{6}$. It is for these reasons that parents are less willing to educate girls than boys in rural India.

Most labour supply models and human capital models have emerged in the context of industrialised countries, and it must be borne in mind that the assumptions underlying them do not always apply in the context of the child schooling decision in developing countries. First, such models assume a smoothly functioning credit market, which is not likely to exist in a context such as rural India ${ }^{7}$. Second, the models are often concerned with the decision to enter further or higher education, not the decision to enter primary school which is of interest here ${ }^{8}$. Third, the models are built on the assumption that choices are made by the individual. In our context, the schooling decision is more likely to be made by adult members of the household ${ }^{9}$ (normally parents).

In view of this last point, any model of the schooling decision should incorporate parents' preferences ${ }^{10}$. Some past studies have achieved this by combining characteristics of the children with those of their parents (Grootaert, 1998; Ray, 1999, 2000a, 2000b; Kambhampati and Pal, 2000). Bhalotra and Heady (1998) go a step further by allowing an inter-generational flow of wealth and human capital accumulation through education and work experiences, in order to take account of the dynamic nature of household decision making ${ }^{11}$.

\subsection{Demographic models}

Demographic models examine the relationship between the demographic characteristics of a child (e.g. number of siblings, birth order) and their educational attainment (as measured by test scores, completed years of schooling, or earnings). These studies are of limited relevance here because they use ex-post data on adolescents or adults, usually in developed countries. The concept of 'zero-

\footnotetext{
${ }^{5}$ Tilak (1987:100) finds that the rate of return to female education turns out to be negative when it is adjusted for non-participation in the labour force.

${ }^{6}$ Brides are normally matched with grooms whose educational levels are equal to or higher than theirs. Since grooms with higher educational level are likely to have better-paid jobs, they tend to command higher amounts of dowry. Parents, who find it hard to raise money for dowry, are reluctant to educate girls.

${ }^{7}$ Tilak (1987:144) states that the credit market in India is "too poorly organised to provide any funds to the people for investing in education."

${ }^{8}$ Kooreman and Wunderink (1996:181) state that most human capital investment models restrict attention to the decisions made by individuals who have completed elementary education. See also Sapsford and Tzannatos (1993:88-93) for further criticism of human capital theory

9 In household interviews, almost all parents and children said that the decision on enrolment to primary school was made by parents. However, see Iversen (2000) for an interesting discussion of 'autonomy' in child labour migrants.

${ }^{10}$ See Becker and Tomes (1976), Behrman, Pollak and Taubman (1982) and Behrman (1988a; 1988b) for household behaviour on intra-household resource allocation (e.g. altruistic, inequality aversion, and reinforcing the difference).

11 There are also some studies which examine inter-generational effects concerning children's schooling by gender (i.e. father-son or mother-daughter nexus). See Drèze and Kingdon (1998), Ray (1999), Kambhampati and Pal (2000).
} 
attainment' (i.e. non-enrolment), which is of interest here, is not normally an issue in these models. Nevertheless, the studies provide some very useful insights.

A demographic model which is widely used is the 'confluence model' of Zajonc et al. (1979), in which two theories are tested. The first is 'resource dilution' which predicts that the more children there are in the household, the lower the educational quality, since the resources of the household, in terms of both material resources and parents' attention, are diluted. The second theory is the 'teaching effect' which predicts that the presence of siblings has a positive influence on educational achievement, through the benefit of either teaching younger siblings, or being taught by older siblings. Empirical studies tend to support the 'resource dilution' theory when the number of children in the household is the explanatory factor. However, studies which have analysed the effects of birth order have generated mixed results on both theories (Steelman and Mercy, 1980; Behrman and Taubman, 1986; Kessher, 1991; Travis and Kohli, 1995).

It is easy to see why results relating to birth order are not consistent. Firstly, earlyborn children may, by the resource dilution effect, enjoy advantages through experiencing less competition for resources in their early years than do their younger siblings, and, by the teaching effect, benefit from having younger siblings to teach. However, later-born children may be better-positioned, because household income normally increases from an early to a late stage of marriage union ${ }^{12}$ and they have many teachers (i.e. their elder siblings). We might therefore expect mid-borns (second-borns, third-borns, ..., but not last-borns) to face the fiercest competition for resources, but to benefit most from the teaching effect. 'Only-children' are of special interest because they have an advantage in terms of resources, but are doubly disadvantaged in terms of the 'teaching effect'.

The nature of competition among siblings also depends to an extent on the sibstructure, particularly sibling gender. Morduch (2000) reports that the number of sisters a child has, has a positive impact on schooling. Similarly, Kessher (1991) finds that females in female-siblings-only households are less disadvantaged than females in mixed-sex-siblings households. On the other hand, Butcher and Case (1994) propose that females with brothers receive more education than females with only sisters. Parish and Willis ${ }^{13}$ (1993) assert that competitive pressure is higher between same-sex siblings.

So we see that birth order can affect the educational attainment of a child in a number of different ways, including complicated interaction effects with sex and sibling composition, resulting in ambiguous predictions. This provides clear motivation for our own detailed investigation of the effect of birth order in a multiple regression context.

\section{The Model}

\footnotetext{
12 Although this applies to salaried workers whose incomes increase with tenure, it may not apply to waged labourers.

${ }^{13}$ They also present an interesting finding that the effect of birth order on the schooling-work decision is observed among low-income households but it decreases among middle- to higher-income households. They, however, argue that resource constraints (i.e. poverty) are one determinant, and credit constraints and socio-cultural contexts are others.
} 
A number of important points have emerged from the literature review of the previous section. Firstly, the child, rather than the household, is the appropriate unit of analysis. Secondly, the constraints faced by a child do not correspond closely to those assumed in traditional labour supply models, such as budget and credit constraints, but, rather, take the form of resource constraints within the household, resulting from the interactions with other household members - siblings, parents, grandparents and so on. Thirdly, in the decision between schooling and work, many different factors are relevant, which may be grouped into three sets of variables: characteristics of the child, the household and the community in which the child lives.

These considerations lead us to a model of the following form (see Binder, 1998). Note that since the data set used in the study is a single cross-section, the model is static. We specify:

$$
S_{i j k}=S\left(I_{i j k}, H_{j k}, C_{k}\right)
$$

where $S_{i j k}$ represents the schooling-work decision pertaining to child $i$ in household $j$ in community $k ; I_{i j k}$ are a set of variables representing the child's characteristics and position in the household ${ }^{14} ; H_{j k}$ contains the characteristics and circumstances of the household; and $C_{k}$ represents features of the community. In accordance with the objectives of the paper, emphasis is placed on demographic variables contained in $I$ and $H$, controlling for the effects of other relevant variables contained in $H$ and $C$. In practice, features of the community such as labour market conditions and pupilteacher ratio at the village school, which are contained in $C$, are proxied by a set of village dummies.

\section{Empirical Analysis}

\subsection{Data}

The data was collected between August and November 1999, from 101 households in six villages, spread between four districts of rural Andhra Pradesh, India. The six villages are: Uyyalawada, Dhobipet, Dandu, Amdapur, Palapadu and Rajbolaram. At least one district was selected from each of the three regions of Andhra Pradesh, in order to ensure high variation in levels of development and agro-climatic conditions. Furthermore, the six villages were selected to maximise the variation in socioeconomic and agricultural development, and the households within each village were selected to maximise variation in household type (e.g. with respect to children's status, income and caste). Of the 101 households surveyed, 18 have only schoolgoing children, 24 have only working children, and the remaining 59 have a mixture of school-going and working children. The 101 households contain a total of 267 children aged between five and fourteen ${ }^{15}$, of which 119 are boys and 148 are girls.

\footnotetext{
${ }^{14}$ Variable set $I$ might be expected to include factors representing a child's innate ability, such as health condition. However, such variables are not included in this study due to non-availability of data.

${ }^{15}$ To focus, as we do, on the five to fourteen age-group is consistent with the Constitution of India which stipulates that employment of children below the age of fourteen years in hazardous occupations is prohibited, and seeks to provide free, compulsory, education for all children up to the age of fourteen.
} 


\subsection{Descriptive Statistics}

Tables 1a and 1b present summary information on the incidence of school-going children. Table 1a reveals the following: girls, in general, appear less likely to go to school than boys; first-borns are less likely to go to school than later-borns regardless of sex; and finally, the likelihood of going to school appears to rise monotonically as birth order increases. Table $1 \mathrm{~b}$ focuses on second-born children, and reveals that their likelihood of schooling is dramatically higher if their older sibling is a girl. However, it is unwise to attempt to draw too many conclusions from such crude analysis. Due to the fact that the opportunity cost of education rises with age, older children are, ceteris paribus, less likely to be attending school than younger children, which may be the reason why birth order appears to have the effect just noted. Son-preference does not appear to apply for first-borns, but it may do for boys as a whole. All of these considerations underline the need for an econometric model in which all of the effects are considered simultaneously.

Table 1a: Incidences of school-going children among children by gender and birth order

\begin{tabular}{c|cccc}
\hline & $\begin{array}{l}\text { No of working } \\
\text { children }\end{array}$ & $\begin{array}{l}\text { No of school- } \\
\text { going children }\end{array}$ & $\begin{array}{l}\text { Total no } \\
\text { children }\end{array}$ & $\begin{array}{c}\text { \% of school- } \\
\text { going children }\end{array}$ \\
\hline Total & 123 & 144 & 267 & $53.93 \%$ \\
Boys & 48 & 71 & 119 & $59.66 \%$ \\
Girls & 75 & 73 & 148 & $49.32 \%$ \\
Only child & 3 & 4 & 7 & $57.14 \%$ \\
Boys & 1 & 1 & 2 & $50.00 \%$ \\
Girls & 2 & 3 & 5 & $60.00 \%$ \\
First-born & 29 & 10 & 39 & $25.64 \%$ \\
Boys & 15 & 6 & 21 & $28.57 \%$ \\
Girls & 14 & 4 & 18 & $22.22 \%$ \\
Mid-born & 63 & 75 & 138 & $54.35 \%$ \\
Boys & 15 & 33 & 48 & $68.75 \%$ \\
Girls & 48 & 42 & 90 & $46.67 \%$ \\
Last-born & 28 & 55 & 83 & $66.27 \%$ \\
Boys & 17 & 31 & 48 & $64.58 \%$ \\
Girls & 11 & 24 & 35 & $68.57 \%$ \\
\hline Sits & & & &
\end{tabular}

Source: Field survey

Table 1b: Incidences of school-going children among second-borns

\begin{tabular}{c|cccc}
\hline & $\begin{array}{l}\text { No of working } \\
\text { children }\end{array}$ & $\begin{array}{l}\text { No of school- } \\
\text { going children }\end{array}$ & $\begin{array}{l}\text { Total no of } \\
\text { children }\end{array}$ & $\begin{array}{l}\text { \% of school- } \\
\text { going children }\end{array}$ \\
\hline Second-born & 36 & 37 & 73 & $50.68 \%$ \\
Boys & 12 & 17 & 29 & $58.62 \%$ \\
Having elder brother & 10 & 5 & 15 & $33.33 \%$ \\
Having elder sister & 2 & 12 & 14 & $85.71 \%$ \\
Girls & 24 & 20 & 44 & $45.45 \%$ \\
Having elder brother & 14 & 9 & 23 & $39.13 \%$ \\
Having elder sister & 10 & 11 & 21 & $52.38 \%$ \\
\hline
\end{tabular}

Source: Field survey 


\subsection{Estimation}

We have estimated various binary Logit models of school attendance, using data on subsets of the 267 children from the 101 households in the sample (due to missing values, the sample size varies according to the model estimated). The dependent variable is one if the child goes to school, and zero otherwise. An interesting possibility would be to consider the schooling and work decisions as separate, and to estimate a bivariate model for the two decisions simultaneously. Such a model is tenable because, as noted in footnote 1, some children neither work nor attend school, and, indeed, some children do both. However, the benefits of such an approach are limited because the numbers of such children are so small ${ }^{16}$. Hence the univariate approach is pursued here.

It has been suggested (Binder, 1998) that when the child is used as the unit of analysis, observations should be weighted inversely to the number of children in the household. We have avoided this strategy, because it suggests that less importance should be attached to children from larger households. All children are equally important, whether they come from large households or small households, and hence we do not weight observations in estimation.

Tables $2 \mathrm{a}$ and $2 \mathrm{~b}$ present the results from six models. Before interpreting their coefficients, we shall outline the model selection procedure which led to the final specification, Model 5.

\subsection{Model Selection}

The main purpose of models 1 through 4 is to try out different combinations of variables, using Akaike's Information Criterion (AIC) ${ }^{17}$ to guide model selection. The advantages of using AIC for this purpose are that it adjusts the goodness-of-fit to allow for the number of parameters in the model, and that it is especially suited to the comparison of non-nested models. AIC has been used intensively in model selection in a cross-section econometric context by Lyons et al. (2001).

The first set of variables listed relates to the child's characteristics: these are included in all models because of their clear significance. The second set of variables listed relates to the child's position in the household, and, since it is here that the focus of the paper lies, it is these variables on which most of the experimentation is performed. It is found that the best specification, and therefore the one used in the final model, is one in which the number of siblings is divided into various categories.

A large number of other variables are tested for significance in different combinations. Those that show significance are included in the final model.

\footnotetext{
${ }^{16}$ When a bivariate probit model is estimated, the correlation coefficient between the two equations' error terms is estimated as -0.979 ; this strong negative correlation is consistent with the very low numbers of children in both or neither activity.

${ }^{17}$ Akaike's Information Criterion is defined as $A I C=(-2 \log L+2 k) / n$, where $\log L$ is the maximised $\log$-likelihood, $k$ is the number of parameters in the model, and $n$ is the sample size. The most preferred model is the one with the smallest AIC.
} 


\subsection{Interpretation of coefficients}

\section{Age and gender}

It appears at first sight, from the negative coefficient of the gender dummy, that male children are less likely to go to school than females. However, this is not the case: we also need to consider the coefficient of the interaction variable, malexage. The positive coefficient of this interaction variable implies that the negative effect of age is greater for girls than for boys (in the final model, the slope is -0.42 for girls and 0.14 for boys). ${ }^{18}$ A consequence is that the logit (and therefore the probability of going to school) is lower for girls than for boys over most of the relevant age range. In fact, as shown in Figure 1, girls have a lower schooling probability at every age over 8.25 years (this is worked out as the ratio of two coefficients $2.303 / 0.279)^{19}$. Moreover, the difference between boys' and girls' probabilities of schooling increases as age rises ${ }^{20}$. This result reaffirms the disadvantaged situation of girls' schooling as well as revealing the dynamic nature of children's status.

Figure 1: Propensity to schooling by sex

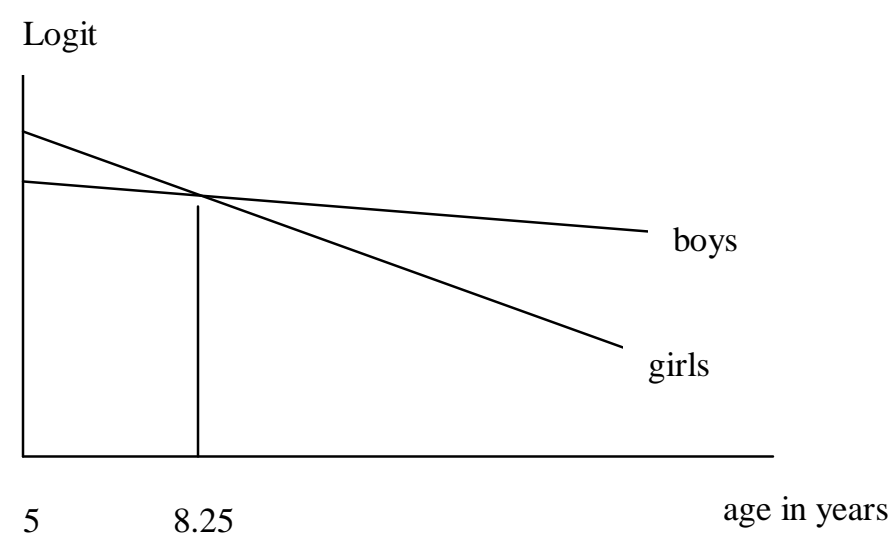

Birth order

One of the major challenges of this paper was how to introduce birth order. Past studies were of little use, since the few that had adopted this variable did so in a simplistic way. For example, Kambhampati and Pal (2000) simply code it as 1, 2, 3, ... from the eldest, while Bhuiya \& Streatfield (1992) and Binder (1998) create dummy variables in a somewhat arbitrary manner. As mentioned in Section 4.4, several different specifications were investigated here. Models 1 and 2 straightforwardly include the child's birth order in the same manner as Kambhampati and Pal (2000), and find that this variable has a significantly positive effect on the

\footnotetext{
${ }^{18}$ A quadratic term in age was included during the specification search, but was found not to be significant.

${ }^{19}$ The enrolment ratio is generally lower for girls than boys in India. The fact that in figure 1 the converse appears to apply to very young children may be because the sample is not representative of the total child population of Andhra Pradesh. The essential point here is that girls are more likely to drop out as they grow older.

${ }^{20}$ The causes of high drop-out rates for girls are socio-cultural, in addition to the economic causes listed in section 2.2. Two examples are early marriage and parents' reluctance to allow girls to travel long distances to school after puberty. See World Bank (1997), Lanjouw and Stern (1998), and the PROBE Team (1999).
} 
probability of schooling ${ }^{21}$. In the discussion of the descriptive statistics in table 1a of section 4.2, the point was made that the birth-order effect noted there may be simply a consequence of the fact that older children, who tend to have a lower birth order, are less likely to attend school. However, in models 1 and 2, we have found that the birth-order effect is a pure effect, and applies even if the age of the child is held constant.

A different strategy is adopted in model 3, which instead uses a set of dummies indicating the child's precise position within the household. Here, it is found that first-borns are significantly less likely to be educated than other children. Perhaps surprisingly in the patriarchal context of rural India, this first-born disadvantage appears to apply to both genders equally ${ }^{22}$.

Models 1-3 are out-performed by a specification in which the number of siblings is divided into various categories (models 4 and 5). Model 5 is the final model ${ }^{23}$ which finds in particular that the number of elder working sisters has a significantly positive effect on schooling ${ }^{24}$, while the number of younger brothers attending school has a significantly negative effect. ${ }^{25}$

These results are consistent with resource dilution theory (see section 2.3), but in a very particular way. There is no doubt that the resource constraint is binding, but it appears to be the eldest sister in the household who bears the burden. In the case of landless households (which make up 63\% of the sample) subsistence depends upon daily wages, so additional workers in the household have the potential to generate a considerable easing of the household's budget constraint. Thus it is seen why the presence of elder working sisters has the observed positive impact on schooling. The negative effect on a child's schooling of the presence of school-going younger brothers appears to constitute evidence of son preference ${ }^{26}$.

\footnotetext{
${ }^{21}$ One question we considered was whether it was appropriate for the last-born in a large household to be assigned a higher 'score' than the last-born in a small household, as is necessarily the case if birth order itself is used. Using the log of birth order instead is a way of reducing any distortion arising from this. This was tried but did not improve the model according to the AIC.

${ }^{22}$ The conclusion that the first-born disadvantage applies to both genders equally was drawn from an unreported model in which an interaction term combining the first-born dummy with gender was introduced and found not to be significant.

${ }^{23}$ Before reaching the final model, a dummy variable distinguishing single-sex from mixed-sex sibconstellations was included, since previous studies have found (see section 2.3) that girls with only sisters may be advantaged relative to girls with brothers and sisters. However, this dummy did not show significance, and the effect of sibling composition is captured better by the categorisation of siblings introduced in model 5.

${ }^{24}$ The negative and significant coefficient on the square of the number of elder working sisters may be interpreted as 'diminishing returns to elder working sisters' and perhaps implies that the presence of such siblings is more important than the number thereof.

${ }^{25}$ It should be said that by dividing up child's position in the household in this very detailed way, we are leaving ourselves open to the problem of endogeneity. The decision to send a sibling to work must, logically, depend to an extent on the schooling decision made for the child under analysis. This, of course, implies that variables like "number of working elder sisters" may be endogenous. The strength of the effects we see in model 5 may be partly explained by this problem. However, to deal with the problem of endogeneity in this context would require estimation of simultaneous equation binary data models, which are certainly beyond the scope of this paper.

${ }^{26}$ See Pearson (1998) who reports that daughters work to finance sons' education.
} 


\section{Other demographic variables}

Model 1 finds that the household size has a non-linear (inverted-U) effect on schooling, with an implied 'optimal' size of six. Models 2 and 3 find a similar effect of the number of school-aged children in the household; the 'optimum' here appears to be around 3.5. When the number of school-aged children in the household is greater than 3.5, the negative effect of this variable on schooling is consistent with the resource dilution theory. However, it must be said that these results are slightly misleading. The fact that the 'optimal' number of school aged children is around 3.5 is a simple consequence of the fact that if a child is a member of this 'optimal' household, he or she is more likely to have an older working sister than if there were only two, say, school aged children. Our rigorous model selection process has revealed that the number of siblings per se is not what is important. Sibling gender and working status are crucially important, and this is precisely the reason why model 5 , which makes this distinction, is found to be superior to all the others estimated.

With regard to household structure, the presence of infants is thought to have a negative effect on schooling, particularly for girls, due to the need to care for them in households with working parents. If grandparents are present in the household as well as infants, the negative effect of the presence of infants is thought to be lower. However, neither of these household traits was found to have an effect.

\section{$\underline{\text { Socio-economic status }}$}

Variables such as income ${ }^{28}$, land-holding, parents' educational level and caste, which past studies have identified as important, are found to be insignificant in this data set. However, the variables asset index ${ }^{29}$, the number of rooms in the house, and a dummy variable for agricultural/waged labour, which also qualify as measures of the economic status of household, show that children of better-off households are more likely to go to school.

Mother's age, rather than parents' educational level which is not significant, appears to be acting as a proxy for the effect of parents' perceived value of education. Its strongly significant negative coefficient shows that the older the mother, the less likely the child is to attend school, ceteris paribus. In $83 \%$ of the sampled households, both parents are illiterate, and it is reasonable to infer that they have no experience in schooling. However, as people's contacts with the world outside their village develop, through for example development of transportation and media, they are likely to become more aware of the benefits of education. Younger mothers are probably more exposed in this way than older mothers, and therefore to be more inclined to educate children.

\footnotetext{
${ }^{27}$ See Table A. 1 in Appendix for the definition of Asset Index.

${ }^{28}$ We have adopted the variable, income group, instead of the actual amount of income, due to the problem of measurement error with income data, particularly for agrarian households (Shariff, 1999). The sample households are divided into five income groups, taking account of income, land-holding, livestock and other assets.

${ }^{29}$ See Table A.1 in Appendix for the definition of Asset Index.
} 


\section{$\underline{\text { Religion (Christian) }}$}

The positive coefficient associated with the Christian dummy indicates that Christians are more likely to educate their children, ceteris paribus. It is known that Christians are keen to educate children (both boys and girls), which is often cited as one of the reasons that the Indian state of Kerala has attained high literacy (Ramachandran, 1997). It appears that the same Christianity effect is at work in our study villages.

\section{$\underline{\text { Village dummy }}$}

The only village showing a significant difference from the others is Dhobipet, where the probability of schooling appears to be higher than that in the other five villages. This can be explained by the fact that a local NGO is operating in Dhobipet with the objective of withdrawing children from work and enrolling them in school, by means of motivating parents and children towards education, but, tellingly, without providing economic assistance. As the model shows, their activities appear to have a positive impact on children's schooling.

\section{$\underline{\text { Models } 6 \mathrm{a}, 6 \mathrm{~b} \text { and } 6 \mathrm{c}}$}

Since we have identified sibling status as a key determinant of the schooling-work decision, it is desirable to examine these effects more closely by isolating the households which contain a mixture of working and school-going children. Since competition between siblings is clearly taking place in these households, potentially more precise results relating to such competition may be obtained by restricting the sample in this way. To allow fully for gender differences, we have estimated the model separately for boys and girls. Table $2 \mathrm{~b}$ includes the results of models $6 \mathrm{a}$ (for boys), $6 \mathrm{~b}$ (for girls) and 6c (for all).

Model 6c certainly provides focused results: children, at any age, are more likely to go to school if they have working elder sisters, and are less likely to go to school if any of their siblings go to school. By comparing models $6 \mathrm{a}$ and $6 \mathrm{~b}$, we can see whether these effects differ by gender. We see that there is one striking difference: for girls, the presence of younger sisters at school has a significantly negative effect on schooling; for boys, their presence has no effect. This close examination of sibling structure reveals that girls are not only disadvantaged by the presence of brothers, but also face competition from sisters, especially younger sisters. 
Table 2a: The results of 5 simple Logit models

Dependent variable: 1 - if child goes to school; 0 - otherwise.

\begin{tabular}{|c|c|c|c|c|c|}
\hline & Model 1 & Model 2 & Model 3 & Model 4 & Model 5 \\
\hline Constant & $-2.864(3.395)$ & $2.488(1.944)$ & $2.151(2.216)$ & $5.783(1.551)^{* * *}$ & $5.988(1.479) * * *$ \\
\hline \multicolumn{6}{|l|}{ Child's characteristics } \\
\hline Male & $-3.314(1.480)^{* *}$ & $-2.514(1.270)^{* *}$ & $-2.771(1.277)^{* *}$ & $-2.989(1.346)^{* *}$ & $-2.303(1.340)^{*}$ \\
\hline Age & $-0.566(0.119) * * *$ & $-0.451(0.098)^{* * * *}$ & $-0.428(0.104)^{* * * *}$ & $-0.455(0.112)^{* * * *}$ & $-0.418(0.104) * * *$ \\
\hline Male×age & $0.418(0.145)^{* * *}$ & $0.318(0.125)^{* *}$ & $0.354(0.127)^{* * *}$ & $0.361(0.133)^{* * *}$ & $0.279(0.132)^{* *}$ \\
\hline \multicolumn{6}{|l|}{ Child's position in household } \\
\hline Birth order & $0.358(0.170)^{* * *}$ & $0.289(0.135)^{* *}$ & & & \\
\hline \# working elder brothers & & & & $0.228(0.257)$ & \\
\hline \# elder brothers at school & & & & $0.002(0.404)$ & \\
\hline \# working elder sisters & & & & $1.955(0.577)^{* * *}$ & $2.310(0.621) * * *$ \\
\hline \# working elder sisters squared & & & & $-0.510(0.282)^{*}$ & $-0.725(0.309)^{* * *}$ \\
\hline \# elder sisters at school & & & & $0.609(0.387)$ & \\
\hline \# younger brothers at school & & & & $-0.561(0.338)^{*}$ & $-0.868(0.337)^{* *}$ \\
\hline \# younger sisters at school & & & & $0.595(0.289)^{* *}$ & \\
\hline First-born & & & $-1.454(0.526) * * *$ & & \\
\hline \multicolumn{6}{|l|}{ Mid-born (base) } \\
\hline Last-born & & & $0.279(0.414)$ & & \\
\hline Only child & & & $0.019(1.156)$ & & \\
\hline \multicolumn{6}{|l|}{ Household characteristics } \\
\hline Household size & $1.943(0.862)^{* *}$ & & & & \\
\hline Household size squared & $-0.150(0.064)^{* *}$ & & & & \\
\hline No of children aged 5-14 & & $1.789(0.890)^{* *}$ & $2.065(0.954)^{* *}$ & & \\
\hline No of children aged 5-14 squared & & $-0.267(0.144)^{*}$ & $-0.283(0.147)^{*}$ & & \\
\hline Presence of infants & $-0.257(0.536)$ & & & & \\
\hline Presence of infants and elderly & $0.118(0.842)$ & & & & \\
\hline Income group & $0.340(0.234)$ & & & & \\
\hline Asset index & & & & & $0.182(0.101)^{*}$ \\
\hline Land-holding & $0.038(0.528)$ & & & & \\
\hline Ownership of livestock & $-0.562(0.436)$ & & & & \\
\hline Agricultural and wage labour & & & & & $-0.687(0.349)^{* *}$ \\
\hline No of rooms & & $0.413(0.179)^{* *}$ & $0.427(0.178)^{* * *}$ & $0.421(0.196)^{* * *}$ & $0.416(0.203)^{* *}$ \\
\hline Fathers' educational level & $-0.012(0.120)$ & & & & \\
\hline Mother's educational level & $-0.264(0.207)$ & & & & \\
\hline Age of mother & & $-0.084(0.033)^{* *}$ & $-0.076(0.031)^{* *}$ & $-0.102(0.035)^{* * * *}$ & $-0.104(0.034)^{* * *}$ \\
\hline \multicolumn{6}{|l|}{ Caste } \\
\hline Scheduled caste & $0.625(0.972)$ & & & & \\
\hline Scheduled tribe & $2.134(1.243)^{*}$ & & & & \\
\hline Backward caste & $-0.159(0.877)$ & & & & \\
\hline \multicolumn{6}{|l|}{ Other castes (base) } \\
\hline \multicolumn{6}{|l|}{ Religion } \\
\hline \multicolumn{6}{|l|}{ Hindu (base) } \\
\hline Muslim & $0.833(1.362)$ & & & & \\
\hline Christian & $1.066(0.847)$ & & & & $0.949(0.507)^{*}$ \\
\hline \multicolumn{6}{|l|}{ Village } \\
\hline \multicolumn{6}{|l|}{ Uyyalawada (base) } \\
\hline Dhobipet & $1.248(0.658)^{*}$ & $1.617(0.464) * * *$ & $1.683(0.475)^{* * *}$ & $1.878(0.537)^{* * *}$ & $2.193(0.529) * * *$ \\
\hline Dandu & $0.085(0.781)$ & & & & \\
\hline Amdapur & $-1.676(1.204)$ & & & & \\
\hline Palapadu & $-0.394(0.668)$ & & & & \\
\hline Rajbolaram & $-1.396(0.856)$ & & & & \\
\hline Sample size (n) & 230 & 252 & 252 & 252 & 252 \\
\hline $\log \mathbf{L}$ & -112.3023 & -132.561 & -130.2289 & -122.143 & -119.9126 \\
\hline Number of parameters (k) & 24 & 10 & 12 & 14 & 13 \\
\hline $\mathrm{AIC}[\equiv(-2 \log L+2 k) / n]$ & 1.1852 & 1.1314 & 1.1288 & 1.0805 & 1.0549 \\
\hline
\end{tabular}

Source: Field survey

Asymptotic standard errors in parentheses.

*** indicates significance at $1 \%$ level.

** indicates significance at $5 \%$ level.

* indicates significance at $10 \%$ level. 
Table 2b: Different effects on boys and girls, restricting sample to "mixed" households

\begin{tabular}{|l|c|c|c|}
\hline & Model 6a (boys) & Model 6b (girls) & Model 6c (all) \\
\hline Constant & $9.954(4.940)^{* *}$ & $7.354(2.848)^{* *}$ & $8.706(2.348)$ \\
\hline Child's characteristics & & & \\
\hline Male & & & $-3.468(2.072)^{*}$ \\
\hline Age & $-0.465(0.269)^{*}$ & $-0.388(0.167)^{* *}$ & $-0.507(0.169)^{*}$ \\
\hline Malexage & & & $0.338(0.202)^{*}$ \\
\hline $\begin{array}{l}\text { Child's position in } \\
\text { household }\end{array}$ & & & \\
\hline \# working elder brothers & $1.268(1.103)$ & $-0.349(0.581)$ & $0.021(0.395)$ \\
\hline \# elder brothers at school & $-5.285(1.625)^{* * *}$ & $-2.026(1.071)^{*}$ & $-3.407(0.811)^{* * *}$ \\
\hline \# working elder sisters & $1.924(0.895)^{* *}$ & $1.148(0.554)^{* *}$ & $1.407(0.422)^{* * *}$ \\
\hline \# elder sisters at school & $-1.982(1.073)^{*}$ & $-0.733(0.806)$ & $-0.924(0.569)$ \\
\hline \# younger brothers at school & $-4.850(1.373)^{* * *}$ & $-2.591(0.871)^{* * *}$ & $-3.402(0.684)^{* * *}$ \\
\hline \# younger sisters at school & $0.654(1.228)$ & $-1.584(0.678)^{* *}$ & $-1.240(0.541)^{* *}$ \\
\hline Household characteristics & & & \\
\hline Asset index & $-0.090(0.424)$ & $0.043(0.166)$ & $0.038(0.153)$ \\
\hline Agricultural and wage labour & $-0.016(0.880)$ & $-0.229(0.759)$ & $-0.493(0.518)$ \\
\hline No of rooms & $1.214(0.934)$ & $0.463(0.416)$ & $0.521(0.339)$ \\
\hline Age of mother & $-0.187(0.125)$ & $-0.081(0.073)$ & $-0.081(0.053)$ \\
\hline Christian & $2.741(1.117)^{* *}$ & $0.466(1.415)$ & $1.873(0.775)^{* *}$ \\
\hline Village & & & \\
\hline Dhobipet & $2.370(1.696)$ & $0.945(1.168)$ & $1.468(0.826)^{*}$ \\
\hline Sample size (n) & 83 & 88 & 171 \\
\hline LogL & -22.610 & -32.702 & -60.189 \\
\hline Number of parameters $(\mathbf{k})$ & 14 & 14 & 16 \\
\hline AIC [ (-2LogL + 2k)/n] & 0.8821 & 1.0614 & 0.8910 \\
\hline
\end{tabular}

Asymptotic standard errors in parentheses.

$$
\begin{aligned}
& * * * \text { indicates significance at } 1 \% \text { level. } \\
& * * \text { indicates significance at } 5 \% \text { level. } \\
& * \quad \text { indicates significance at } 10 \% \text { level. }
\end{aligned}
$$

\section{Conclusion}

Previous studies of the determinants of child labour and schooling have been biased towards factory workers and the effects of household characteristics such as the level of household income. They tend to overlook the majority of child workers in rural areas and to lack consideration to competition among siblings within a household with respect to the opportunity for education. It was these two perceived shortcomings of the existing literature that motivated this research.

The fieldwork provided useful insights in the development of the empirical models used. In one household interview, a father with three school-age children explained his own decision: "... one for wage work, one for domestic work and one for schooling, because I am unable to sustain life if all of my children attend school." ${ }^{30}$ In another interview, parents explained that "all girls worked for the son" ${ }^{31}$, meaning that girls were working in order to finance their brother's education. Examples such as these make it clear that a thorough study of child labour must delve into the intrahousehold decision-making process, in addition to taking due account of the characteristics of the household and community.

\footnotetext{
${ }^{30}$ Field Survey (30/9/1999).

${ }^{31}$ Field survey $(7 / 11 / 1999)$.
} 
Of the child's characteristics, age and sex are the most important determinants of the work-schooling decision. In addition, we have hypothesised that the child's position within the household is relevant, and is the key to capturing sibling rivalry. A number of our results are in agreement with previous studies, for example, the evidence that boys are more likely to attend school than girls, and drop-out rates are higher among girls. However, we do not find evidence of the prevailing view that eldest sons are given priority to education. Instead, we have found evidence that key factors in the schooling decision are the presence of working elder sisters and school-going younger brothers, and that boys compete within the same sex (i.e. with their brothers) while girls face double competition: first with brothers and then with sisters. Older sisters appear to be the most disadvantaged.

Two theories which emerged as important in the literature survey of section 2.3 were the resource dilution theory and the teaching effect. A number of our results favour resource dilution theory. It has been harder to find evidence in favour of the teaching effect, as it was in previous studies cited in section 2.3.

Household economic status (represented by asset level, housing conditions and occupational type), have a modest influence on children's schooling. The negative effect of mother's age has been interpreted as indicating that awareness of the importance of education plays a role. This is also shown by the significant positive premium on schooling probability exhibited by the village of Dhobipet, which has been attributed to the NGO's activities aimed at increasing interest in children's education in that village.

The clear policy implication of this work is that the difference in schooling status of children within the same household should be borne in mind. Simply targeting lowerincome households would not be sufficient to achieve universal elementary education. While such targeting may alter the mix of school-going and working children within the targeted households, there is no guarantee that every disadvantaged child will benefit. What is clearly vital is to pay attention to each individual child who is disadvantaged in schooling.

Although the findings summarised here must be considered within the specific context of the survey villages, it is hoped that they will be useful in guiding future lines of research on the determinants of children's work and schooling, and perhaps also in policy formation. 


\section{Appendix}

Table A.1: Definition of variables

\begin{tabular}{|c|c|}
\hline Name of variable & Definition \\
\hline Male & 1: boy, 0: girl \\
\hline Age & Age of a child \\
\hline Male×age & Interaction term of male and age \\
\hline Birth order & Birth order of a child: $1,2,3 \ldots$ from the eldest \\
\hline \# working elder brothers & No of working elder brothers \\
\hline \# elder brothers at school & No of elder brothers at school \\
\hline \# working elder sisters & No of working elder sisters \\
\hline \# working elder sisters squared & No of working elder sisters squared \\
\hline \# elder sisters at school & No of elder sisters at school \\
\hline \# younger brothers at school & No of younger brothers at school \\
\hline \# younger sisters at school & No of younger sisters at school \\
\hline First-born & 1: first-born child, 0 : otherwise \\
\hline Mid-born (base) & 1: mid-born child, 0 : otherwise \\
\hline Last-born & 1: last-born child, 0 : otherwise \\
\hline Only child & 1: only-child, 0 : otherwise \\
\hline Household size & No of household members \\
\hline Household size squared & Square of no of household members \\
\hline No of children aged 5-14 & No of children aged between 5 and 14 \\
\hline No of children aged 5-14 squared & Square of no of children aged between 5 and 14 \\
\hline Presence of infants & 1: if infant(s) is present, 0 : otherwise \\
\hline Presence of infants and elderly & 1: if infant(s) and elderly are present, 0 : otherwise \\
\hline Income group & Quintile income groups (5: the wealthiest, ..., 1: the poorest) \\
\hline Asset index & $\begin{array}{l}\text { Sum of points given to assets (TV:4, radio: } 1 \text {, casette: } 1 \text {, bike: } 1 \text {, } \\
\text { fun: } 1 \text {, camera:1) }\end{array}$ \\
\hline Land-holding & 1: if a household owns land, 0 : otherwise \\
\hline Ownership of livestock & 1: if a household owns livestock, 0 : otherwise \\
\hline Agricultural and wage labour & $\begin{array}{l}\text { 1: if a household's main occupation is agricultural labour or wage } \\
\text { labour, 0: otherwise }\end{array}$ \\
\hline No of rooms & No of rooms in which a child lives \\
\hline Fathers' educational level & Father's completed years of schooling \\
\hline Mother's educational level & Mother's completed years of schooling \\
\hline Age of mother & Age of mother \\
\hline Scheduled caste & 1: if a household belongs to scheduled caste, 0 : otherwise \\
\hline Scheduled tribe & 1: if a household belongs to scheduled tribe, 0 : otherwise \\
\hline Backward caste & 1: if a household belongs to backward castes, 0 : otherwise \\
\hline Other castes (base) & 1: if a household belongs to other castes, 0 : otherwise \\
\hline Hindu (base) & 1: if a household's religion is Hindu, 0 : otherwise \\
\hline Muslim & 1: if a household's religion is Muslim, 0: otherwise \\
\hline Christian & 1: if a household's religion is Christianity, 0: otherwise \\
\hline Uyyalawada (base) & 1: if a child lives in Uyyalawada, 0: otherwise \\
\hline Dhobipet & 1: if a child lives in Dhobipet, 0 : otherwise \\
\hline Dandu & 1: if a child lives in Dandu, 0: otherwise \\
\hline Amdapur & 1: if a child lives in Amdapur, 0: otherwise \\
\hline Palapadu & 1: if a child lives in Palapadu, 0: otherwise \\
\hline Rajbolaram & 1: if a child lives in Rajbolaram, 0 : otherwise \\
\hline
\end{tabular}


Table A.2: Means and standard deviations of variables used for regression analyses

\begin{tabular}{|c|c|c|c|}
\hline & No of observation & Mean & SD \\
\hline Male & 267 & 0.45 & 0.50 \\
\hline Age & 267 & 9.84 & 2.67 \\
\hline Male×age & 267 & 4.32 & 5.16 \\
\hline Birth order & 267 & 2.92 & 1.47 \\
\hline \# working elder brothers & 267 & 0.43 & 0.70 \\
\hline \# elder brothers at school & 267 & 0.23 & 0.47 \\
\hline \# working elder sisters & 267 & 0.50 & 0.66 \\
\hline \# working elder sisters squared & 267 & 0.69 & 1.27 \\
\hline \# elder sisters at school & 267 & 0.26 & 0.55 \\
\hline \# younger brothers at school & 267 & 0.36 & 0.55 \\
\hline \# younger sisters at school & 267 & 0.39 & 0.65 \\
\hline First-born & 267 & 0.15 & 0.35 \\
\hline Mid-born (base) & 267 & 0.52 & 0.50 \\
\hline Last-born & 267 & 0.31 & 0.46 \\
\hline Only child & 267 & 0.03 & 0.16 \\
\hline Household size & 267 & 6.45 & 2.06 \\
\hline Household size squared & 267 & 45.78 & 34.12 \\
\hline No of children aged 5-14 & 267 & 3.06 & 0.94 \\
\hline No of children aged 5-14 squared & 267 & 10.22 & 5.72 \\
\hline Presence of infants & 267 & 0.21 & 0.41 \\
\hline Presence of infants and elderly & 267 & 0.08 & 0.27 \\
\hline Income group & 267 & 3.00 & 1.16 \\
\hline Asset index & 267 & 1.07 & 1.80 \\
\hline Land-holding & 267 & 0.49 & 0.50 \\
\hline Ownership of livestock & 267 & 0.57 & 0.50 \\
\hline Agricultural and wage labour & 267 & 0.39 & 0.49 \\
\hline No of rooms & 254 & 1.89 & 0.97 \\
\hline Fathers' educational level & 232 & 0.48 & 1.47 \\
\hline Mother's educational level & 265 & 0.17 & 1.04 \\
\hline Age of mother & 265 & 33.24 & 5.69 \\
\hline Scheduled caste & 267 & 0.42 & 0.49 \\
\hline Scheduled tribe & 267 & 0.17 & 0.38 \\
\hline Backward caste & 267 & 0.32 & 0.47 \\
\hline Other castes & 267 & 0.05 & 0.22 \\
\hline Hindu & 267 & 0.82 & 0.38 \\
\hline Muslim & 267 & 0.04 & 0.20 \\
\hline Christian & 267 & 0.13 & 0.34 \\
\hline Uyyalawada & 267 & 0.21 & 0.41 \\
\hline Dhobipet & 267 & 0.17 & 0.38 \\
\hline Dandu & 267 & 0.19 & 0.39 \\
\hline Amdapur & 267 & 0.09 & 0.28 \\
\hline Palapadu & 267 & 0.13 & 0.34 \\
\hline Rajbolaram & 267 & 0.21 & 0.41 \\
\hline
\end{tabular}

Source: Field survey 


\section{References}

Alderman, H. and Gertler, P., 1997, 'Family Resources and Gender Differences in Human Capital Investment: the Demand for Children's Medical Care in Pakistan' in Haddad, L., Hoddinott, J. and Alderman, H., Intrahousehold Resource Allocation in Developing Countries, Baltimore and London: The Johns Hopkins University Press.

Anker, R., Barge, S, Rajagopal, S. and Joseph, M.P., 1998, Economics of Child Labour in Hazardous Industries of India, New Delhi: Hindustan Publishing Corporation (India).

Becker, G.S. and Lewis, H.G., 1973 'On the Interaction Between the Quantity and Quality of Children', Journal of Political Economy, Vol.82, No.2 (special).

Becker, G.S. and Tomes, N., 1976, 'Child Endowments and the Quantity and Quality of Children', Journal of Political Economy, Vol.84, Part2.

Behrman, J.R., 1988a, 'Nutrition, Health, Birth-order and Seasonality: Intrahousehold Allocation among Children in Rural India', Journal of Development Economics, Vol.28, No.1.

Behrman, J.R., 1988b, 'Intra-Household Allocation of Nutrients in Rural India: Are Boys Favoured? Do Parents Exhibit Inequality Aversion?', Oxford Economic Papers, Vol.40, No.1.

Behrman, J.R., Pollak, R.A. and Taubman, P., 1982, 'Parental Preferences and Provision for Progeny'. Journal of Political Economy, Vol.90, No.1.

Behrman, J.R. and Taubman, P., 1986, 'Birth-order, Schooling and Earning', Journal of Labour Economics, Vol.4, No.3.

Bhalotra, S. and Heady, C., 1998, 'Child Labour in Pakistan and Ghana', Department of Economics, University of Bristol (mimeo).

Bhatty, K., 1998, 'Educational Deprivation in India: A Survey of Field Investigations', Economic and Political Weekly, Vol.XXXIII, No.27 and No.28.

Bhuiya, A. and Streatfield, K., 1992, 'A Hazard Logit Model Analysis of Covariates of Childhood Mortality in Matlab, Bangladesh', Journal of Biosocial Science, Vol.24, No.4.

Binder, M., 1998, 'Family Background, Gender and Schooling in Mexico', Journal of Development Studies, Vol.35, No.2.

Burra, N., 1995, Born to Work: Child Labour in India, Delhi: Oxford University Press.

Butcher, K.F. and Case, A., 1994, 'The Effect of Sibling Sex Composition on Women's Education and Earnings', The Quarterly Journal of Economics, Vol.CIX, No.3.

Drèze, J. and Kingdon, G.G., 1999, 'School Participation in Rural India', Delhi School of Economics and University of Oxford (mimeo).

Government of India, 1991, The Census of India 1991, New Delhi: Office of Registrar General, Government of India.

Grootaert, C., 1998, 'Child Labour in Côte d'Ivoire: Incidence and Determinants', Washington D.C., the World Bank, Policy Research Working Paper, No.1905.

Hossain, S.I., 1990, 'Interrelations between Child Education, Health and Family Size: Evidence from a Developing Country', Economic Development and Cultural Change, Vol.38, No.4.

Iversen, V., 2000, Autonomy in child labour migrants from rural Karnataka, University of East Anglia (mimeo). 
Jafarey, S. and Lahiri, S., 1999, Will Trade Sanctions Reduce Child Labour?: Role of Credit Markets. University of Essex (mimeo).

Kambhampati U. and S. Pal., 2000, 'School participation among boys and girls in India: the role of household income and parental bargaining', Cardiff Business School Discussion Papers in Economics, No. 00:043.

Kanbargi R., 1991, Child Labour in the Indian Subcontinent: Dimensions and Implications, New Delhi: Sage.

Kessler, D., 1991, 'Birth-order, Family-size, and Achievement: Family structure and Wage Determination', Journal of Labour Economics, Vol.9, No.4.

Kooreman, P. and Wunderink, S., 1996, The Economics of Household Behaviour, London: Macmillan Press Ltd.

Lanjouw, P. and Stern, N., 1998, Economic Development in Palanpur over Five Decades, Oxford: Clarendon Press.

Levy, V., 1985, 'Cropping Pattern, Mechanisation, Child Labour and Fertility Behaviour in a Farming Economy: Rural Egypt', Economic Development and Cultural Change, Vol.33, No.4.

Lieten, G.K., 2000, 'Children Work and Education India: General Parameters - part I -', and 'Field Work in 2 UP Village - part II -‘, Economic and Political Weekly, Vol.XXXV, No.24 and No.25.

Lyons, B., C. Matraves and P. Moffatt, 2001, "Industrial Concentration and Market Integration in the European Union", Economica, 68, 1-26.

McKechnie, J. and Hobbs S. (1998) Working children: Reconsidering the Debates. Amsterdam, International Working Group on Child Labour.

Mishra, L., 2000, Child Labour in India, Delhi: Oxford University Press.

Morduch, J., 2000, 'Sibling Rivalry in Africa', The American Economic Review, Vol.90, No.2.

Nardinelli, C., 1990, Child Labour and the Industrial Revolution, Bloomington and Indianapolis: Indiana University Press.

Parish, W.L. and Willis, R.J., 1993, 'Daughters, Education and Family Budgets: Taiwan Experiences', The Journal of Human Resources, Vol.XXVIII, No.4.

Pearson, R., 1998, 'Nimble Fingers Revisited: Reflections on Women and Third World Industrialisation in the Late Twentieth Century' in Jackson, C. and Pearson, R., Feminist Visions of Development: Gender, Analysis and Policy, London and New York: Routledge.

The PROBE Team, 1999, Public Report on Basic Education in India, New Delhi: Oxford University Press.

Psacharopoulos, G., 1997, 'Child Labour versus Educational Attainment: Some Evidence from Latin America', Journal of Population Economics, Vol.10, Part 4.

Psacharopoulos, G. and Woodhall, M., 1985, Education for Development: An Analysis of Investment Choices, New York: Oxford University Press.

Ramachandran, V.K., 1997, 'On Kerala's Development Achievements' in Drèze, J. and Sen, A.K., Indian Development: Selected Regional Perspectives, Delhi: Oxford University Press.

Ray, R., 1999, 'How Child Labour and Child Schooling Interact with Adult Labour; the World Bank, Policy Research working Paper, No.2179. 
Ray, R., 2000a, 'Analysis of Child Labour in Peru and Pakistan: A Comparative Study', Journal of Population Economics, Vol.13, No.1.

Ray, R., 2000b, The Determinants of Child Labour and Child Schooling in Ghana, School of Economics, University of Tasmania (mimeo).

Rosenzweig, M.R., 1982, 'Educational Subsidy, Agricultural Development and Fertility Change', Quarterly Journal of Economics, Vol.XCVII, No.1.

Rosenzweig, M.R. and Evenson, R., 1977, 'Fertility, Schooling, and the Economic Contribution of Children in Rural India: An Econometric Analysis', Econometrica, Vol.45, No.5.

Rosenzweig, M.R. and Wolpin, K.I., 1982, 'Governmental Interventions and Household Behaviour in a Developing Country', Journal of Development Economics, Vol. 10.

Sapsford, D. and Tzannatos, Z., 1993, The Economics of the Labour Market, London: Macmillan.

Shariff, A., 1999, Indian Human Development Report: A Profile of Indian States in the 1990s, New Delhi: Oxford University Press.

Steelman L.C, and Mercy, J.A., 1980, 'Unconfounding the Confluence Model: A Test of Sibship Size and Birth-order Effects on Intelligence', American Sociological Review, Vol.45.

Strauss, J. and Tomas, D., 1995, 'Human Resources: Empirical Modelling of Household and Family Decisions' in Behrman, J. and Srinivasan, T.N., Handbook of Development Economics - Vol. III-A, Amsterdam: Elsevier Science Publishers, B.V.

Tilak, J.B.G., 1987, The Economics of the Inequality in Education, Delhi: Sage Publications.

Travis, R. and Kohli, V., 1995, 'The Birth-order Factor: Ordinal Position, Social Strata and Educational Achievement', Journal of Sociological Psychology, Vol.135, No.4.

Weiner, M., 1991, The Child and the State in India: Child Labour and Education Policy in Comparative Perspective, Princeton and New Jersey: Princeton University Press.

World Bank, 1997, Primary Education in India, Washington D.C.:the World Bank.

Zajonc, R.B., Markus, H., and Markus, G.B., 1979, 'The Birth Order Puzzle', Journal of Personality and Social Psychology, Vol.37, No.8. 